\title{
PENGARUH PEMBERIAN SARI BATANG NANAS (ANANAS COMOSUS) TERHADAP TOTAL LEUKOSIT TIKUS WISTAR YANG DIBERI PAPARAN ASAP ROKOK
}

\author{
Nungki Dwi Permatasari, Enny Probosari *) \\ Program Studi Ilmu Gizi Fakultas Kedokteran Universitas Diponegoro \\ Jl.Dr.Sutomo No.18, Semarang, Telp (024) 8453708, Email : gizifk@undip.ac.id
}

\begin{abstract}
Background: Cigarette smoke is a central factor in many pathological conditions. Cigarette smoke increases leukocyte count which is associated with an increased in CVD. Bromelain is a proteinase from pineapple stem which has anti-inflammatory agents. The purpose of this research was to determine the effect of pineapple stem juice on leukocyte total in wistar rats which are exposed to cigarette smoke.

Method: Sixteen male wistar rats were classified into three groups. All of them were exposed to cigarette smoke 2 cigarettes sticks for each group. It was done for 30 days. First group was control group, second group was treatment group which was given $20 \mathrm{mg} / \mathrm{kg}$ weight of stem bromelain, and third group was treatment group which was given 40 $\mathrm{mg} / \mathrm{kg}$ weight of stem bromelain. Blood samples were obtained on the 31th day by plexus retro orbitalis after 12-hour fasting. Leukocyte total was counted by blood analyzer Mikros 6.0. Normality test was done by Shapiro-Wilk test and parametric statistic analysis was done by One Way ANOVA test.

Results: one way ANOVA test result found significant effect of pineapple stem juice on total leukocyte $(p=0.43)$. The

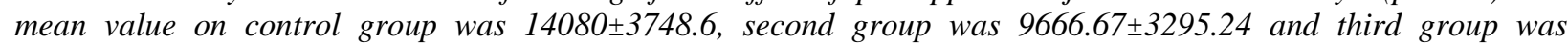
$9380 \pm 1020.784$. There was significant differences in total leukocytes between first group and second group $(p=0.029)$, significant differences between first and third group $(p=0.026)$, and no significant differences between second and third group $(p=0.876)$
\end{abstract}

Conclusion: There was significant effect of pineapple stem juice consumption on total leukocyte wistar rats exposed to cigarette smoke $(p<0.05)$

Keywords: pineapple stem juice, bromelain, leukocyte total, cigarette smoke

\section{ABSTRAK}

Latar Belakang: Asap rokok merupakan faktor yang berpengaruh dalam keadaan patologis. Paparan asap rokok dapat meningkatkan total leukosit dimana akan menaikkan risiko penyakit kardiovaskular. Diketahui terdapat zat anti inflamasi untuk mengendalikan total leukosit yaitu enzim bromelain yang banyak terkandung dalam batang nanas. Penelitian ini bertujuan untuk mengetahui pengaruh pemberian sari batang nanas terhadap total leukosit tikus wistar yang diberi paparan asap rokok.

Metode: Enam belas tikus dibagi menjadi 3 kelompok. Seluruh kelompok diberikan paparan asap rokok 2 batang/hari selama 30 hari. Tiga kelompok adalah kelompok kontrol, kelompok perlakuan 1 yang diberi 20 mg/kgBB bromelain dan kelompok perlakuan 2 diberi $40 \mathrm{mg} / \mathrm{kgBB}$ bromelain. Hari ke 31 diambil sampel darah melalui plexus retro orbitalis setelah berpuasa selama 12 jam. Total leukosit dihitung dengan menggunakan alat blood analyzer Mikros 6.0. Uji normalitas menggunakan Shapiro-wilk dan uji one way ANOVA

Hasil: Uji ANOVA menunjukkan terdapat pengaruh pemberian sari batang nanas ( $p=0.43)$. Rerata jumlah leukosit

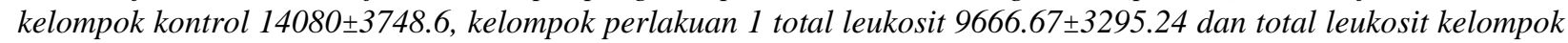
perlakuan 2 adalah 9380 \pm 1020.784 . Secara statistik terdapat perbedaan rerata antara kelompok kontrol dan perlakuan 1 ( $p=0.029)$, terdapat perbedaan rerata kelompok kontrol dan perlakuan $2(p=0.026)$, dan tidak terdapat perbedaan rerata kelompok perlakuan 1 dan perlakuan $2(p=0.876)$

Kesimpulan: Terdapat pengaruh pemberian sari batang nanas terhadap total leukosit tikus wistar yang diberi paparan asap rokok $(p<0.05)$

Kata kunci: sari batang nanas, enzim bromelain, total leukosit, paparan asap rokok

\section{PENDAHULUAN}

Asap rokok adalah suatu hal yang mudah sekali dijumpai di lingkungan sekitar kita. Menurut data Riskesdas pada tahun 2013 sebanyak 36.3\% penduduk Indonesia berusia lebih dari 15 tahun adalah perokok aktif. Angka tersebut mengalami peningkatan sebelumnya yang pada tahun 2007 terdapat $34,2 \%$ penduduk perokok aktif. ${ }^{1}$ Kenaikan jumlah perokok di Indonesia sebanding dengan tingginya morbiditas dan mortalitas akibat rokok. Di Indonesia asap rokok menyebabkan 9,8\% kematian karena penyakit paru kronik dan emfisema pada tahun 2001. Asap rokok tidak hanya berdampak bagi perokok aktif, namun juga perokok pasif. Lebih dari 43 juta anak Indonesia berusia 014 tahun tinggal dengan perokok di lingkungannya mengalami pertumbuhan paru yang lambat dan lebih mudah terkena infeksi saluran pernafasan,

\footnotetext{
${ }^{*}$ Penulis Penanggungjawab
} 
infeksi telinga dan asma. ${ }^{2}$ Sedangkan penyakit yang paling utama adalah penyakit jantung dan stroke. Satu dari tiga kematian di dunia berhubungan dengan penyakit jantung dan stroke. ${ }^{2}$ Kedua penyakit tersebut dapat menyebabkan kematian mendadak atau sudden death. Semakin lama dan semakin banyak terkena paparan asap rokok, maka semakin tinggi pula risiko terkena penyakit.

Asap rokok mengandung berbagai zat berbahaya bagi tubuh. Terdapat sekitar $10^{7}$ molekul oksidan per batang. ${ }^{3}$ Kandungan yang paling berbahaya dari rokok adalah nikotin. Nikotin merupakan salah satu zat beracun yang bekerja sangat cepat. Ketika asap rokok masuk kedalam tubuh maka terjadi respon inflamasi ditunjukkan dengan naiknya produksi mediator pro inflamasi yang nantinya akan menaikkan jumlah total leukosit dalam darah.

Leukosit atau sel darah putih adalah sel darah yang berperan khusus sebagai sistim imunitas. Seseorang yang mendapatkan paparan asap rokok dalam jangka waktu yang lama secara terus menerus memiliki jumlah leukosit $20-25 \%$ lebih tinggi dibandingkan orang yang tidak merokok. ${ }^{4}$ Terdapat hubungan positif yang kuat antara merokok dengan jumlah total leukosit pada perokok. ${ }^{5}$ Mekanisme kenaikan leukosit pada perokok masih belum diketahui secara jelas. Namun diketahui nikotin dapat menyebabkan leukositosis dengan bersirkulasinya catecholamine karena kenaikan hormon seperti epinephrine dan kortisol yang pada akhirnya akan meningkatkan jumlah total leukosit. ${ }^{7}$ Bagian leukosit yang mengalami peningkatan adalah polymorphonuclear neutrophil (PMN). ${ }^{4}$

Leukositosis yang terjadi pada perokok menjadi faktor risiko berbagai penyakit sistim imun, salah satunya adalah faktor risiko penyakit jantung koroner dan penurunan fungsi paru-paru. ${ }^{4,5}$ Sedangkan, penurunan total leukosit sebanyak 9$25 \%$ berhubungan dengan penurunan risiko penyakit kardiovaskular sebanyak $14 \%$. Perokok yang berhenti merokok akan mengalami penurunan jumlah total leukosit, walaupun selama lebih dari tiga tahun jumlah total leukositnya masih tergolong tinggi. Membutuhkan waktu beberapa tahun untuk dapat menurunkan jumlah total leukosit kembali normal. $^{5}$ Penurunan jumlah leukosit dapat dipengaruhi oleh faktor asupan terutama yang mengandung antioksidan. Namun tidak hanya antioksidan, terdapat zat anti inflamasi yang diketahui mampu untuk menurunkan jumlah total leukosit yaitu enzim bromelain dimana enzim tersebut banyak terkandung dalam batang nanas (Ananas comosus)
Bromelain adalah salah satu enzim proteolitik pada tanaman seperti enzim papain dalam getah buah pepaya. Karena sifatnya sebagai proteolitik, dalam bidang industri enzim bromelain dan papain digunakan sebagai bahan pelunak daging, proses pemanggangan dan pencegah reaksi pencoklatan pada sari apel. ${ }^{7}$ Namun yang menjadi keunggulan bromelain adalah memiliki kegunaan anti inflamasi yang tidak dimiliki oleh papain. Sehingga bromelain lebih banyak dimanfaatkan dalam bidang kesehatan.

Batang nanas adalah salah satu bagian dari tanaman nanas (Ananas comosus) yang jarang dimanfaatkan. Padahal dalam batang nanas memiliki kandungan enzim bromelain yang tinggi. Enzim paling banyak ditemukan pada stem bromelain (SBR) atau bromelain yang terdapat pada batang nanas daripada fruit bromelain (FBR) atau bromelain pada buah nanas itu sendiri. ${ }^{7}$ Konsentrasi bromelain yang paling tinggi pada batang nanas, biasanya dibutuhkan ekstraksi untuk dimanfaatkan. Berbeda dari buah nanas yang memang wajar dikonsumsi sebagai makanan, batang adalah bagian sisa yang tidak terpakai dari tumbuhan nanas serta harganya relatif lebih murah. ${ }^{8}$ Dalam penelitian ini peneliti tidak melakukan ekstraksi enzim bromelain, namun menggunakan sari batang nanas karena sari adalah bentuk yang mudah untuk diaplikasikan dalam masyarakat.

Enzim bromelain memiliki kegunaan yang penting sebagai anti inflamasi pada berbagai penyakit inflamasi kronis, keganasan dan penyakit autoimun. Pemberian secara oral bromelain terbukti dapat menjadi analgesic dan anti inflamasi pada pasien rheumatik arthritis, dimana merupakan penyakit autoimun yang sering dijumpai. ${ }^{9,10}$ Efek menguntungkan dari bromelain telah dibuktikan pada berbagai penyakit inflamasi dan hewan uji coba. Penelitian sebelumnya juga membuktikan bahwa bromelain dapat menurunkan limfosit $\mathrm{CD}^{4+}$ secara signifikan, yang mana merupakan inflamasi utama pada model hewan. ${ }^{9,11}$ Hasil yang sama ditunjukkan bahwa bromelain dapat menurunkan migrasi neutrofil secara signifikan pada inflamasi akut dan membantu untuk mengembalikan reseptor $\mathrm{CD}^{128}{ }^{12}$ Bahkan penelitian pada tahun 2011 menunjukkan bahwa bromelain dapat menjadi zat baru untuk dapat menormalkan motilitas usus pada penyakit inflamasi dan diabetes. ${ }^{13}$

Penelitian terdahulu pada tikus Sprague dawley, membuktikan bahwa bromelain pada dosis 20 dan $40 \mathrm{mg} / \mathrm{kg}$ memiliki efek anti inflamasi. ${ }^{14,15}$ Pada penelitian ini digunakan tikus wistar karena memiliki ketahanan tubuh yang cukup kuat untuk hidup dengan paparan asap rokok. Untuk itu, 
peneliti ingin mengetahui pengaruh pemberian sari batang nanas (Ananas comosus) terhadap total leukosit tikus wistar yang diberi paparan asap rokok.

\section{METODE PENELITIAN}

Penelitian ini merupakan penelitian posttest only with randomized control group design. Variabel bebas (independent variable) dalam penelitian ini adalah pemberian sari batang nanas yang diberikan dengan 2 dosis yaitu 20 $\mathrm{mg} / \mathrm{kgBB} / \mathrm{hari}$ dan $40 \mathrm{mg} / \mathrm{kgBB} / \mathrm{hari}$. Variabel terikat (dependent variable) adalah total leukosit tikus wistar. Variabel terkontrol (control variable) adalah pemaparan asap rokok 2 batang/hari, galur, jenis kelamin, pakan dan sistim perkandangan hewan coba. Pelaksanaan penelitian ini telah mendapatkan persetujuan dari Komite Etik Penelitian Kesehatan Fakultas Kedokteran Universitas Diponegoro dengan terbitnya Ethical Clearance.

Batang nanas (Ananas comosus) varietas Cayenne berusia 2 tahun didapatkan dari petani nanas di Wonosari. Batang nanas setelah dipanen dipisahkan dari daun, akar, tanah dan dicuci dengan air sampai bersih. Batang nanas dipotong-potong menjadi bagian kecil dan dihaluskan dengan juicer kemudian disaring untuk menghilangkan bagian ampasnya. Sari batang nanas murni yang sudah didapatkan tidak ditambahkan air, disimpan dengan suhu penyimpanan refrigerator untuk mencegah kerusakan enzim bromelain. Berdasarkan tinjauan literatur yang didapatkan, dalam $0,1 \mathrm{ml}$ sari batang nanas berusia 2 tahun mengandung enzim bromelain sebanyak $0,095 \mathrm{mg}$.

Penelitian ini dilakukan di Laboratorium Fisiologi Hewan Fakultas MIPA Universitas Negeri Semarang untuk pemeliharaan hewan coba, sedangkan pemeriksaan total leukosit dilakukan di Balai Laboratorium Kesehatan Provinsi Jawa Tengah. Perhitungan sampel minimal hewan coba berdasarkan WHO adalah 5 ekor setiap kelompok, untuk mengantisipasi drop out maka jumlah sampel 6 ekor setiap kelompok. Hewan coba yang digunakan adalah tikus wistar jantan dengan pertimbangan hewan jantan tidak memiliki banyak hormon seperti hewan betina yang dapat mempengaruhi total leukosit. Tikus wistar jantan yang digunakan berusia 6 minggu yaitu usia dewasa awal. Jika terlalu muda maka regenerasi sel terlalu cepat dan jika terlalu tua maka regenerasi sel akan sangat lambat jika terjadi kerusakan oksidatif akibat paparan asap rokok. Usia dewasa awal atau usia siap kawin pada hewan coba tikus adalah rentang usia yang sesuai untuk regenerasi sel-sel termasuk sel leukosit. Pada usia dewasa awal berat badan tikus berkisar antara 150-200 gram.

Delapan belas tikus dibagi menjadi 3 kelompok secara acak, yaitu kelompok kontrol, perlakuan 1 dan perlakuan 2. Keseluruhan kelompok mendapatkan paparan asap yang berasal dari pembakaran 2 batang rokok perhari selama 30 menit. Kelompok kontrol tidak diberikan sari batang nanas, kelompok perlakuan 1 diberikan sari batang nanas sebanyak 3,1 ml/hari dan kelompok perlakuan 2 diberikan sari batang nanas sebanyak $6,2 \mathrm{ml} / \mathrm{hari}$. Pemberian sari batang nanas diberikan sebanyak $2 x$ dengan pertimbangan jumlah maksimal lambung tikus $\pm 5 \mathrm{cc}$. Pemberian sari batang nanas 1 jam setelah pemaparan asap rokok, dan pemberian kedua selang 1 jam setelah pemberian pertama. Pemberian sari batang nanas dengan menggunakan metode sonde, dilakukan sejak hari ke 1.

Pemaparan asap rokok dilakukan setiap hari dengan cara memasukkan tikus dalam kotak berukuran $30 \mathrm{~cm} \times 40 \mathrm{~cm} \times 50 \mathrm{~cm}$ dengan ukuran ventilasi $5.6 \mathrm{~cm} \times 28.4 \mathrm{~cm}$. Rokok yang dibakar adalah jenis rokok kretek non filtered merk "D" dengan kandungan tar $2.4 \mathrm{mg}$ dan nikotin $38 \mathrm{mg}$ per batang. Pemaparan asap rokok dilakukan selama 30 menit setiap harinya.

Pada hari ke 31 darah sampel diambil melalui plexus retro orbitalis sebanyak $\pm 1 \mathrm{cc}$ setelah berpuasa selama 12 jam. Total leukosit dianalisis dengan menggunakan alat blood analyzer Mikros 6.0.

Data diolah dengan program komputer. Uji normalitas data menggunakan uji Saphiro-Wilk. Uji parametrik menggunakan one way ANOVA kemudian dilanjutkan dengan uji ANOVA lanjut Post Hoc LSD untuk menentukan perbedaan pengaruh antar tiap kelompok.

\section{HASIL PENELITIAN}

Penelitian pada hari ke 31 terdapat tikus yang drop out sehingga data akhir pada kelompok kontrol, perlakuan 1 dan perlakuan 2 masingmasing 5, 6, dan 5 ekor. Enam belas tikus diambil darah untuk dianalisis total leukosit. Data post-test total leukosit yang telah didapat diuji normalitasnya secara deskriptif dengan melihat histogram dan boxplot (Lampiran). Secara analitis, data diuji distribusi normalitasnya menggunakan uji Saphirowilk karena sampel kurang dari 50 kemudian dilakukan uji Levene untuk mengetahui homogenitas varians.

Hasil dari uji normalitas Shapiro-wilk data pada tiap kelompok berdistribusi normal (kontrol $p=0.764$, perlakuan $1 p=0.226$, perlakuan 2 
$p=0.308 ; p>0.05)$. Kemudian hasil dari uji Levene didapatkan homogenitas sama. Karena semua data berdistribusi normal dan homogenitas sama, dilanjutkan dengan uji parametrik one way Anova yang dijelaskan dalam tabel berikut

Tabel 1. Rerata Total Leukosit post-test

\begin{tabular}{|c|c|c|c|c|}
\hline & Kelompok & $\mathbf{n}$ & Rerata \pm SD & $p$ \\
\hline \multirow{3}{*}{ Total leukosit } & Kontrol & 5 & $14080 \pm 3748.6$ & \multirow{3}{*}{0.043} \\
\hline & Perlakuan 1 & 6 & $9666.67 \pm 3295.249$ & \\
\hline & Perlakuan 2 & 5 & $9380 \pm 1020.784$ & \\
\hline
\end{tabular}

Uji one way ANOVA

Hasil analisis one way ANOVA didapatkan $p$ hitung 0.043 lebih kecil dari $\mathrm{F}$ tabel yaitu 4.035 atau $p<0.05$. Dapat disimpulkan bahwa Ho ditolak atau terdapat pengaruh pemberian sari batang nanas terhadap total leukosit. Berdasarkan tabel diatas diketahui rerata total leukosit pada kelompok kontrol lebih tinggi pada kelompok perlakuan. Total leukosit pada kelompok kontrol 14080 \pm 3748.6 $\mathrm{sel} / \mathrm{mm}^{3}$, pada kelompok perlakuan 1 adalah
$9666.67 \pm 3295.249 \mathrm{sel} / \mathrm{mm}^{3}$ dan kelompok perlakuan 2 adalah $9380 \pm 1020.784 \mathrm{sel} / \mathrm{mm}^{3}$. Histogram rerata total leukosit dapat dilihat pada Lampiran. Karena Ho ditolak atau terdapat pengaruh, maka data dianalisis dengan uji ANOVA lanjut post-hoc $L S D$ untuk mengetahui pengaruh antar tiap kelompok. Hasil uji lanjut dapat dilihat pada Tabel 2 berikut

Tabel 2. Perbedaan Rerata Tiap Kelompok

\begin{tabular}{|c|c|c|c|c|}
\hline & \multirow{2}{*}{ Perbedaan rerata } & \multicolumn{2}{|c|}{ IK $95 \%$} & \multirow{2}{*}{$p$} \\
\hline & & Minimum & Maksimum & \\
\hline $\begin{array}{l}\text { Kontrol Vs } \\
\text { perlakuan } 1\end{array}$ & 4413.33333 & 528.1139 & 8298.5528 & 0.029 \\
\hline $\begin{array}{l}\text { Kontrol vs } \\
\text { perlakuan } 2\end{array}$ & 4700.00000 & 642.0207 & 8757.9793 & 0.026 \\
\hline $\begin{array}{l}\text { Perlakuan } 1 \text { vs } \\
\text { perlakuan } 2\end{array}$ & 286.66667 & -3598.5528 & 4171.8861 & 0.876 \\
\hline
\end{tabular}

Hasil dari uji post-hoc diketahui bahwa rerata antara kelompok kontrol dan perlakuan 1 nilai $p=0.029$, kelompok kontrol dan perlakuan 2 $p=0.026$, kelompok perlakuan 1 dan perlakuan 2 $p=0.876$. Berdasarkan nilai $p$ dapat disimpulkan terdapat perbedaan yang bermakna antara rerata kelompok kontrol-perlakuan 1 dan kelompok kontrol-perlakuan 2 , serta tidak ada perbedaan yang bermakna antar tiap kelompok perlakuan.

\section{PEMBAHASAN}

Penelitian ini merupakan penelitian posttest only with randomized control group design dimana semua kelompok diberikan paparan asap rokok kemudian dilakukan analisis akhir total leukosit. Pemaparan asap rokok ke hewan coba bertujuan untuk meningkatkan total leukosit karena adanya inflamasi dari zat dalam asap rokok. Pembakaran rokok akan memanaskan udara yang ada didalam rokok, kemudian udara yang panas akan menyebakan nikotin dan zat lain menguap. Ketika asap dihembuskan dan udara kembali dingin, beberapa komponen akan berkondensasi menjadi ukuran partikel. Perokok aktif maupun pasif menghisap nikotin bercampur aerosol dengan ukuran partikel mikron dan mengendap dalam alveolar kemudian secara cepat akan diserap dalam peredaran darah. Selain nikotin, asap rokok mengandung molekul polycyclic aromatic hydrocarbons (PAH). Zat tersebut merupakan senyawa radikal bebas dari fase tar dan fase gas rokok, yang dapat memproduksi reactive oxygen species (ROS). Senyawa radikal bebas terbentuk saat reaksi rantai pernafasan dalam mitokondria dari aktivasi dari makrofag dan neutrofil serta senyawa radikal oksigen endogen lain. ${ }^{16}$

Selama penelitian berlangsung, terdapat 2 tikus yang mati pada kelompok kontrol. Mekanisme kematian belum diketahui secara jelas. Pada kelompok kontrol ini terjadi stress oksidatif karena hanya dilakukan pemaparan asap rokok kretek 2 batang/hari selama 30 hari. ${ }^{17}$ Paparan asap rokok 2 batang/hari merupakan dosis rendah, sedangkan dosis tinggi mencapai 20 batang/hari. ${ }^{18}$ Asap rokok yang dipaparkan ke hewan coba termasuk dalam fase gas dimana memiliki waktu paruh lebih singkat yaitu hanya beberapa detik, berbeda dengan fase tar yang memiliki waktu paruh beberapa jam sampai 
hitungan bulan. ${ }^{17}$ Namun perokok pasif (sidestream smoke) menghisap komponen yang lebih berbahaya daripada perokok aktif (mainstream smoke). ${ }^{17}$ Seseorang yang mendapatkan paparan asap rokok memiliki risiko $30 \%$ lebih besar untuk terkena penyakit pembuluh darah koroner yang fatal, walaupun perokok pasif ini dari menghisap sekitar seperseratus dari asap perokok aktif. ${ }^{17}$

Berdasarkan hasil post-test yang diperoleh, jumlah total leukosit pada kelompok kontrol lebih tinggi daripada kelompok perlakuan dengan rerata $14080 \pm 3748.6 \mathrm{sel} / \mathrm{mm}^{3}$. Mekanisme kenaikan total leukosit belum diketahui secara jelas namun kandungan racun dalam asap rokok menjadi hal yang berpengaruh. Paparan asap rokok mempengaruhi respon imun adaptif dan humoral. Kandungan dalam asap rokok salah satunya nikotin ketika masuk kedalam tubuh akan menyebabkan bersirkulasinya cathecolamine kemudian menaikan hormon ephinephrine dan kortisol yang akan meningkatkan total leukosit. ${ }^{7}$ Kenaikan total leukosit ini menjadi respon alamiah tubuh karena masuknya zat asing. Penelitian in vitro dan in vivo sebelumnya membuktikan bahwa paparan asap rokok menaikkan pelepasan sitokin pro inflamasi seperti TNF- $\alpha$, IL-1, IL-6, IL-8 serta penghambatan sitokin anti inflamasi seperti IL-10. ${ }^{19}$ Naiknya berbagai sitokin pro inflamasi menaikkan interaksi antara sel endotel dengan leukosit yang juga akan meningkatkan pembentukan leukosit. ${ }^{17}$ Pembentukan leukosit ini terjadi pada sumsum tulang dimana asap rokok juga menstimulasi sistem hematopoietic. ${ }^{20}$ Jenis leukosit yang mengalami peningkatan adalah neutrofil, ${ }^{5,7,20}$ namun tidak dilakukan pengujian jumlah neutrofil. Dalam penelitian ini juga diketahui terjadi peningkatan jumlah limfosit secara signifikan. Peningkatan jenis leukosit ini diakibatkan karena keluarnya sitokin pro inflamasi yaitu IL-8 yang menginduksi mobilisasi neutrofil dan limfosit $\mathrm{T}$ dari sumsum tulang. ${ }^{21}$

Data yang diperoleh pada kedua kelompok perlakuan menunjukkan hasil post-test total leukosit yang lebih rendah daripada kelompok kontrol. Total leukosit kelompok perlakuan 1 adalah $9666.67 \pm 3295.249 \mathrm{sel} / \mathrm{mm}^{3}$ dan kelompok perlakuan 2 adalah $9380 \pm 1020.784 \mathrm{sel} / \mathrm{mm}^{3}$. Menurut uji post-hoc LSD terdapat rerata perbedaan yang bermakna antar kelompok kontrol dengan kelompok perlakuan. Hal ini dikarenakan enzim bromelain pada sari batang nanas pada kelompok perlakuan memiliki efek anti inflamasi, sedangkan pada kelompok kontrol tidak diberikan zat anti inflamasi sehingga terjadi perbedaan rerata yang bermakna. Pada rerata antar kelompok perlakuan diperoleh hasil tidak bermakna secara statistik. Dosis yang diberikan pada kelompok perlakuan mengacu pada dosis efektif bromelain sebagai anti inflamasi. Penelitian terdahulu pada tahun 2013 pada tikus Sprague dawley menunjukkan bahwa bromelain memiliki efek anti inflamasi pada dosis 20 dan $40 \mathrm{mg} / \mathrm{kgBB} .{ }^{15}$ Perhitungan dosis tersebut dihitung dengan estimasi rata-rata berat badan tikus yaitu $0.15 \mathrm{~kg}$, sehingga pada kelompok perlakuan 1 dan perlakuan 2 diberikan masing-masing $3 \mathrm{mg}$ dan $6 \mathrm{mg}$ bromelain yang terdapat pada $3.1 \mathrm{ml}$ dan 6.2 $\mathrm{ml}$ sari batang nanas.

Mekanisme enzim bromelain dalam menurunkan total leukosit belum diketahui secara jelas. Namun secara umum, enzim bromelain menurunkan plasmakinin dan prostaglandin dimana menjadi mediator inflamasi. Penelitian in vitro menunjukkan bahwa bromelain aktif secara proteolitik menurunkan ekspresi mRNA dalam mengkode sitokin pro inflamasi pada leukosit manusia. ${ }^{22}$ Selain itu, masih pada penelitian in vitro menunjukkan bromelain memiliki kemampuan dalam mengatur adhesi molekul pada sel $\mathrm{T}$, makrofag, sel NK dan juga menginduksi sekresi IL$1 \beta$, IL-6 dan TNF- $\alpha .{ }^{12}$ Mekanisme utama bromelain sebagai proteolitik juga sebagai immunomodulator seperti mengaktivasi melalui jalur sinyal intraselular.

Enzim bromelain merupakan enzim proteolitik dimana dalam strukturnya mengandung protease. Beberapa individu yang memiliki hipersensitif, protein dapat menjadi pemicu reaksi alergi. Pada kelompok perlakuan terdapat beberapa sampel yang nilai leukositnya tinggi, dapat dilihat pada Lampiran. Dapat dicurigai hewan yang memiliki nilai leukosit jauh lebih tinggi tersebut mengalami hipersensitif sehingga nilai eosinofil meningkat tinggi sebagai respons alergi. Namun, karena keterbatasan penelitian ini tidak meneliti jumlah eosinofil. Pada kelompok perlakuan terjadi perubahan perilaku seperti menggaruk-garuk badan. Beberapa tikus pada kelompok perlakuan juga mengalami diare selama beberapa waktu. Namun, peneliti tidak dapat menarik kesimpulan karena tidak ada data biokimia untuk mendukung adanya alergi.

Enzim bromelain adalah ekstrak kasar pada tanaman nanas. Umumnya, enzim bromelain yang berasal dari batang nanas dipisahkan dengan isolasi atau ekstraksi untuk digunakan sebagai efek kesehatan. Namun, enzim bromelain yang digunakan dalam penelitian ini diberikan dalam bentuk sari batang nanas. Menurut penelitian terdahulu, dalam $1 \mathrm{ml}$ sari batang nanas mengandung bromelain sebanyak $0,095 \mathrm{mg}$ 
bromelain. ${ }^{23}$ Enzim bromelain yang berasal dari batang nanas stabil sampai suhu $-20^{\circ} \mathrm{C} .{ }^{24}$ Pada penelitian ini sari batang nanas yang telah didapatkan disimpan pada suhu refrigerator selama sampai \pm 30 hari. Enzim bromelain telah banyak digunakan sebagai zat anti inflamasi di luar negeri. Food and Drug Administration (FDA) USA telah menyatakan bromelain aman dikonsumsi secara oral dan telah mengkategorikan sebagai suplemen makanan.

\section{SIMPULAN}

Pemberian sari batang nanas berpengaruh terhadap total leukosit tikus wistar yang diberi paparan asap rokok. Terdapat perbedaan yang bermakna antara rerata total leukosit kelompok kontrol dengan kelompok perlakuan, namun perbedaan rerata total leukosit antar kelompok perlakuan tidak bermakna secara statistik.

\section{SARAN}

Aplikasi dosis bromelain untuk manusia dalam menurunkan respon inflamasi yaitu pada dosis $126 \mathrm{mg}$ dan $252 \mathrm{mg}$ bromelain atau setara dengan 132,6 $\mathrm{ml}$ dan 265,2 $\mathrm{ml}$ sari batang nanas.

\section{DAFTAR PUSTAKA}

1. Badan Penelitian dan Pengembangan Kesehatan. Riset Kesehatan Dasar. Jakarta: Kementrian Kesehatan Republik Indonesia; 2013.

2. Prihatiningsih, Puji. Jurnal Lingkungan Keluarga. Dampak Merokok Bagi Kesehatan. BKKBN. Edisi II, 2007: 1-5.

3. Smith CJ, Fischer TH. Particulate and vapor phase constituents of cigarette mainstream smoke and risk of myocardial infarction. Atherosclerosis. 2001;158:257-67.

4. T Terashima, B Wiggs, D English, J C Hogg, and S $F$ van Eeden "The effect of cigarette smoking on the bone marrow." American Journal of Respiratory and Critical Care Medicine, Vol. 155, No. 3 (1997), pp. 1021-6. doi: 10.1164/ajrccm.155.3.9116981.

5. Muhammad Jamal Haider, Abdul Rauf. Smoking Habit and Their Association with Total Leukocytes Count among Healthy Men in Karachi, Pakistan. World Appl. Sci. J. 11 (6): 669-673, 2010. ISSN: 1818-4952.

6. Kapoor, D and T.H. Jones. Smoking and Hormones in Health ang Endocrine Disorders. Eur. J. Endocrinol; 2005. 152(4): 491-499.

7. Muntari Bala, Nurul Azira Ismail, Maizirwan Mel, Mohamed Saedi Jami, Hamzah Mohd. Saleh, Azura Amid. Bromelain Production: Current Trends and Perspective. Archives Des Sciences. Vol 65, No. 11;Nov 2012.ISSN 1661-464X.

8. Heinecke, R.M and W.A. Gortner. Stem bromelain, a new protease preparation from pineapple plants. Economic Botany, 11: 225-234; 1957.
9. Rajendra Pavan, Sapna Jain, Shraddha, Ajay Kumar. Properties and Therapeutic Application of Bromelain: A Review. Hindawi Publishing Corporation Biotechnology Research International. Vol 2012, ID 976203, 6 pages doi: $10.1155 / 2012 / 976203$.

10. Chit Moy Ley, Amalia Tsiami, Qing Ni, Nicola Robinson. A Review of the use of bromelain in cardiovascular diseases. Journal of Chinese Integrative Medicine, July 2011, vol 9, No.7.

11. Tochi et al. Theraupetic Application of Pineapple Protease (Bromelain): A Review. Bromelain's Pharmacology. Pakistan Journal of Nutrition 7 (4): 513-520, 2008. ISSN 1680-5194.

12. David J. Fitzhugh, Siqing Shan, Mark W. Dewhirst, Laura P. Hale. Bromelain treatment decreases neutrophil migration to sites of inflammation. Clinical Immunology (2008) 128, 66-74.

13. F. Borrelli et al. Inhibitory effect of bromelain, a cysteine protease derived from pineapple stem (Ananas comosus), on intestinal motility in mice. Neurogastroenterol Motil, 2011, 23, 745-e331. doi: $10.1111 / \mathrm{j} .1365-2982.2011 .01735$.

14. Sri Agus Sudjarwo. Anti-Inflammatory and Analgesic Effect of Bromelain in Mice and Rats. Universa Medicina. Oktober-Desember 2005, Vol.24 No. 4

15. Hidayat, Ricky. Efek Analgesik dan Anti-Inflamasi Sari Buah Nanas (Ananas comosus, L.) Pada Mencit Betina Galur Swiss. [skripsi]. Universitas Sanata Dharma Yogyakarta; 2010.

16. J.A. Ambrose, R.S. Barua. The Pathophysiology of cigarette smoking and cardiovascular disease. J Am Coll Cardiol. 2004;43(10):1731-1737. doi:10.1016/j.jacc.2003.12.047

17. Fajrunni'mah Rizana. Pengaruh Pemberian Sari Noni Terhadap Selisih Jumlah Total Leukosit, Jumlah Neutrofil, dan Kadar Alkalifosfatase pada Tikus Wistar Sebelum dan Sesudah Diberi Paparan Asap Rokok. Diponegoro University Institutional Repository: 2011.

18. D'hulst Al, Vermalen KY, Bruselle GG, Joos GF, Pauwels RA. Time course of cigarette smokeinduced pulmonary inflammation in mice. Eur Respir J. 2005: 204-213.

19. Iho S, Tanaka Y. Takauji R, Kobayashi C, Muramatsu I, Iwasaki $\mathrm{H}$, et al. Nicotine induces human neutrophils to produce IL-8 through the generation of peroxynitrite and subsequent activation of NF-kappaB. J Leukoc Biol. 2003;74:942-51.

20. Y. Arnson et al. Effect of tobacco smoke on immunity, inflammation and autoimmunity. Journal of Autoimmunity 34 (2010) J258-J265. doi:10.1016/j.jaut.2009.12.003

21. Taub DD, Anver M, Oppenheim JJ, Longo DL, Murphy, WJ. T lymphocyte recruitment by interleukin-8 (IL-8). J Clin Invest. 1996;97:193141. 
22. Jane E. Onken, PaulaK. Greer, Brian Calingaert, Laura P. Hale. Bromelain treatment decreases secretion of pro-inflammatory cytokines and chemokines by colon biopsies in vitro. Clinical Immunology. Volume 126, Issue 3, March 2008, Pages 345-352. doi:10.1016/j.clim.2007.11.002

23. Anannya Mohapatra, V. Madhavo Rao, Mala Ranjan. Comparative Study of the Increased Production \& Characterization of Bromelain from the Peel, Pulp \& Stem Pineapple (Anannus commas). International Journal of Advencements in Research \& Technology,Vol 2, Issue 8, August2013. ISSN 2278-776

24. Jutamongkon MR. Factors Affecting the Stability of Fruit Bromelain in Smooth Cayenne Pineapple (Ananas comosus). [Thesis]. Kasetsart University. 